\title{
Brazil and Colombia: Comparative Race Relations in South America
}

Link to publication record in Manchester Research Explorer

\section{Citation for published version (APA):}

Wade, P. (2012). Brazil and Colombia: Comparative Race Relations in South America. In F. Bethencourt , \& A. J. Pearce (Eds.), Racism and Ethnic Relations in the Portuguese-Speaking World (pp. 35-48). (Proceedings of the British Academy; Vol. 179). Oxford University Press.

\section{Published in:}

Racism and Ethnic Relations in the Portuguese-Speaking World

\section{Citing this paper}

Please note that where the full-text provided on Manchester Research Explorer is the Author Accepted Manuscript or Proof version this may differ from the final Published version. If citing, it is advised that you check and use the publisher's definitive version.

\section{General rights}

Copyright and moral rights for the publications made accessible in the Research Explorer are retained by the authors and/or other copyright owners and it is a condition of accessing publications that users recognise and abide by the legal requirements associated with these rights.

\section{Takedown policy}

If you believe that this document breaches copyright please refer to the University of Manchester's Takedown Procedures [http://man.ac.uk/04Y6Bo] or contact uml.scholarlycommunications@manchester.ac.uk providing relevant details, so we can investigate your claim.

\section{OPEN ACCESS}




\title{
Brazil and Colombia: Comparative Race Relations in South America
}

\author{
PETER WADE
}

\section{Introduction}

IN THE LAST TWENTY YEARS OR SO, there has been an explosion of scholarly research into what might be called 'blackness' in Latin America, involving studies of Afro-descendants, black people and race relations. ${ }^{1}$ The tendency has been towards country-based studies, and comparison, where it has taken place, has mostly followed the well-worn path of placing Brazil in relation to the United States. Some important work has questioned the terms of this standard contrast, challenging the 'methodological nationalism'2 that it entails and highlighting how such case-study comparisons can erase the dynamic dialogues and exchanges that take place between the 'cases' and that, in some sense, actually constitute the cases as such. ${ }^{3}$ Other work has pointed out the ongoing and longstanding exchanges and dialogues that link Brazil to Africa across a more southerly version of Gilroy's Black Atlantic. ${ }^{4}$ Less work has sought to make comparisons within Latin America.

\footnotetext{
1 George Reid Andrews, 'Afro-Latin America: Five Questions', Latin American and Caribbean Ethnic Studies 4:2 (2009), pp. 191-210; Peter Wade, 'Afro-Latin Studies: Reflections on the Field', Latin American and Caribbean Ethnic Studies 1:1 (2006), pp. 105-24; Peter Wade, Race and Ethnicity in Latin America, 2nd edn (London: Pluto Press, 2010).

${ }^{2}$ Andreas Wimmer and Nina Glick Schiller, 'Methodological Nationalism and Beyond: Nation-State Building, Migration and the Social Sciences', Global Networks: A Journal of Transnational Affairs 2 (2002), pp. 301-34.

${ }^{3}$ Micol Seigel, Uneven Encounters: Making Race and Nation in Brazil and the United States (Durham, NC: Duke University Press, 2009); see also Ann Laura Stoler, 'Tense and Tender Ties: The Politics of Comparison in North American History and (Post) Colonial Studies', Journal of American History 88:3 (2001), pp. 829-65.

${ }^{4}$ Paul Gilroy, The Black Atlantic: Modernity and Double Consciousness (London: Verso, 1993); J. Lorand Matory, Black Atlantic Religion: Tradition, Transnationalism, and Matriarchy in the AfroBrazilian Candomblé (Princeton: Princeton University Press, 2005); J. Lorand Matory, 'The "New World" Surrounds an Ocean: Theorizing the Live Dialogue between African and African American
} 
Some of the work that has tackled this line of enquiry comes out of political 1 science, where a common mode of enquiry compares different political systems 2 with a view to finding out the key variables that influence political outcomes. ${ }^{5}$ In 3 this direction, Juliet Hooker has recently outlined some useful broad categories 4 with which to think about how different countries have dealt with black and 5 indigenous minorities in the context of a region-wide shift, which has occurred 6 since about 1990, towards the official adoption of multiculturalist policies and 7 definitions of national identity. ${ }^{6}$ She identifies a first category of countries in which 8 indigenous and black groups have come to be seen as basically the same and have 9 been incorporated into national legislation on more or less the same basis, as 10 equivalent ethnic minorities. This category includes Guatemala, Honduras and 11 Nicaragua, countries where the Afro-descendant population is strongly represented 12 by Garifuna populations, which have managed to define themselves as indigenous- 13 like, autochthonous minorities - although not without competing discourses making 14 reference to a more cosmopolitan blackness. ${ }^{7}$ Nicaragua is a more complex case, $\quad 15$ due to the presence in the Atlantic coastal region of black creole people, who have 16 a rather different history from the Garifuna.

Hooker identifies a second category of countries where indigenous peoples are accorded a number of rights (to land, cultural autonomy, bilingual education, and so on), while black people are more or less ignored in legislative terms. Venezuela and Mexico are currently examples of this category. Finally, a third category consists of countries where indigenous peoples are seen as ethnic minorities, with certain, often quite substantial rights, at least on paper, while black people are seen as what Hooker calls 'cultural groups' and 'racial groups', which may get some land rights, although less than those of indigenous peoples, and may also be the beneficiaries of some institutional actions designed to combat racism and/or its effects. In this category, Hooker places Brazil, Colombia, Ecuador and Peru.

This categorisation puts Brazil and Colombia together as similar cases and, indeed, they share some common traits. However, it also masks some important

Cultures', in Kevin Yelvington (ed.), Afro-Atlantic Dialogues: Anthropology in the Diaspora (Santa Fe, NM: School of American Research Press, 2006), pp. 151-92; Kevin Yelvington (ed.), Afro-Atlantic Dialogues: Anthropology in the Diaspora (Santa Fe, NM: School of American Research Press, 2006). ${ }^{5}$ Juliet Hooker, 'Indigenous Inclusion/Black Exclusion: Race, Ethnicity and Multicultural Citizenship in Contemporary Latin America', Journal of Latin American Studies 37:2 (2005), pp. 285-310; Donna Lee Van Cott, The Friendly Liquidation of the Past: The Politics of Diversity in Latin America (Pittsburgh: University of Pittsburgh Press, 2000).

${ }^{6}$ Juliet Hooker, Race and the Politics of Solidarity (Oxford: Oxford University Press, 2009), pp. 137-8.

${ }^{7}$ Mark Anderson, Black and Indigenous: Garifuna Activism and Consumer Culture in Honduras (Minneapolis: University of Minnesota Press, 2009). Garifuna (also known as Garinagu and Black Caribs) are the descendants of a process of mixture between Africans and Carib indigenous populations exiled in the eighteenth century from St Vincent, a British colony in the eastern Caribbean, to islands off the coast of Honduras, whence they spread along the coasts of Honduras, Guatemala, Belize, and Nicaragua.

\section{\begin{tabular}{l}
1 \\
\hline \\
1 \\
1 \\
1 \\
1 \\
3 \\
4 \\
4 \\
5 \\
6 \\
17 \\
18
\end{tabular}}


Racism-00-p.qxd 7/2/12 11:28 Page 37

divergences, as I will show below. Furthermore, the reference to Afro-descendants as both 'cultural' and 'racial' groups points to, but leaves unexplored, the complexity and ambiguity of the 'black' category and the way its definition has ambivalently shifted between different kinds of criteria.

In this essay, I will focus on Brazil and Colombia in the context of the official multiculturalism which both countries have adopted. I will look primarily at 'blackness' but will necessarily make reference to the category 'indigenous', as this is an inherent part of the processes by which identities come to be reckoned, defined, claimed and contested in both countries. I will map out how blackness in each country wavered and oscillated between 'ethnic' and 'racialised' definitions, both from an official and social movement point of view, and how oscillation was related to different contexts, race-ethnic relations and political conjunctures. In brief, in Colombia, we can see a move between 1991 and 2009, from a very 'ethnic' definition towards a more explicitly 'racialised' one, while in Brazil, we can see a move from a pre-1988 racial definition, towards a more ethnic one, which however coexists with a more racial definition. Clearly, these are not opposed trajectories - or even separate 'cases' which are unrelated to each other. Instead they should be seen as variations on a theme of changing, overlapping and often conflicting definitions, all of which are taking place in a transnational, indeed globalising, context of post-colonial identity politics and struggles for human rights and, sometimes, reparative justice. ${ }^{8}$ Brazil and Colombia together highlight the fundamental ambiguity of blackness in the Latin American context: black people have long been (dis)located as both the same as and different from other people in the nation; perhaps culturally distinctive, perhaps just ordinary (if in practice secondclass) citizens; as marginal to, but also at the heart of the nation.

\section{Colombia}

Before the constitutional reform of 1991, black people in Colombia figured in various ways in the national imaginary. ${ }^{9}$ Despite some academic claims made that Afro-Colombians had been made entirely 'invisible' in the nation, there were some conditional spaces for blackness. Los negros was a generalised race/class term used by many people to refer to people identified as 'looking black', in Colombian terms, and used by the middle and upper classes to refer generically to the lower classes,

\footnotetext{
${ }^{8}$ Claudia Mosquera Rosero-Labbé and Luiz Claudio Barcelos (eds), Afro-reparaciones: Memorias de la esclavitud y justicia reparativa para negros, afrocolombianos y raizales (Bogotá: Universidad Nacional de Colombia, 2007).

${ }^{9}$ Peter Wade, Blackness and Race Mixture: The Dynamics of Racial Identity in Colombia (Baltimore: Johns Hopkins University Press, 1993); Peter Wade, Music, Race and Nation: Música Tropical in Colombia (Chicago: University of Chicago Press, 2000).
} 
Racism-00-p.qxd 7/2/12 11:28 Page 38

seen as generally rather 'dark', without much attention to specific features of 1 appearance and ancestry. Negro was, and still is, a racial category in popular usage, 2 as were blanco, indio and other race/colour terms such as moreno (brown). An 3 individual person might be nicknamed el negro, perhaps because he or she was 4 the darkest one of the family, without necessarily being very African-looking; a 5 man might call his romantic partner mi negra, as a term of endearment - one which, 6 however, evoked a history of sexualised racial domination in which black (and 7 indigenous) women were relatively accessible to whiter, higher-status men. ${ }^{10} \quad 8$

Another instance of the presence of blackness was the irruption of music from 9 the Caribbean coastal region of the country - styles such as cumbia and porro - 10 onto the national popular music scene of the 1940s and 1950s, where it was 11 identified as 'black', even though it was rapidly undergoing a process of whitening 12 as part of its entry into middle- and upper-class social clubs. ${ }^{11}$

The most obvious manifestation of blackness in ideas about the nation, however, 14 was in the delineation of a regional geography for the country, stemming in large 15 part from a number of nineteenth-century expeditions to map the nation and its 16 human and natural resources, such as the Comisión Corográfica of the 1850s. The 17 nation was described as comprising a number of distinct provinces and/or 'natural 18 regions', ${ }^{12}$ which were geographically, climatically, culturally, and racially 19 distinctive. The division of the country by province or region varied by classifier 20 and over time, but in broad terms a mode of categorisation solidified in which the 21 Andean interior was the seat of government, wealth, urbanity and whiteness. The 22 Caribbean coastal region was much more black and indigenous, but it was the 23 Pacific coastal region which figured as the black region par excellence, while also 24 being the poorest, the least healthy and the area least conducive to progress and 25 modernity. In fact, then, as now, black people lived in large numbers in many 26 areas of the country, including in areas of the interior of the country, but this did 27 not prevent the Pacific (and to a lesser extent the Caribbean) region from signifying 28 blackness within the nation. This, in turn, also tended to constitute blackness as 29 rather marginal in the nation - geographically and developmentally. 30

Despite the popularity of Caribbean costal music, blackness was never included 31 in representations of the nation in quite the same way as in Cuba or Brazil: in this 32 sense blackness was indeed 'invisible'. Colombian elites might recognise the 33 mixedness of their nation, but the preferred image of the country was a very whitened 34 mestizo - a trend that arguably continues today with such national figures as the pop 35 stars Carlos Vives and Shakira, and the emblem of Colombian coffee, 'Juan Valdez', 36 a branded construct which represents a generic Colombian highland coffee farmer. 37

$\begin{array}{lr} & 38 \\ & 39 \\ { }^{10} \text { Peter Wade, Race and Sex in Latin America (London: Pluto Press, 2009). } & 40 \\ { }^{11} \text { Wade, Music, Race and Nation. } & 41 \\ { }^{12} \text { Francisco Vergara y Velasco, Nueva geografía de Colombia, 3 vols (1901; Bogotá: Banco de la } & 42 \\ \text { República, 1974). } & \end{array}$


In the 1970s and 1980s, when a few anthropological voices began to contest the definition of Colombian anthropology as the study of indigenous peoples - a bias in which Colombia followed other Latin American countries - the status of the Pacific coastal region as the black region of the country became consolidated, as anthropologists focused on blackness as 'other', as culturally distinctive, as linked through antique roots to a non-Western history (Africa), in short as an ethnic minority. ${ }^{13}$ These anthropologists did, in fact, study blackness in other areas of the country as well, but the Pacific coast was already pre-constructed to amplify any attention paid to it as a black area.

At the same time, there emerged the beginnings of a black social movement, fomented by university students, mainly from the Pacific coastal region, who had gone to the universities of the large cities of the interior to study. ${ }^{14}$ They were inspired more by transnational exemplars of blackness - Martin Luther King, Malcolm X, Léopold Senghor, Aimé Césaire - than by local figures, but the fact that they themselves came from the Pacific coastal region helped cement its predominance as the symbol of blackness in the country. This black movement began to adopt the imagery of the runaway slave, the maroon or cimarrón-imagery used in the Caribbean and also in Brazil (the quilombo) - and in fact this highlighted the key role of a small village in the Caribbean coastal region, called Palenque de San Basilio, where descendants of a maroon slave settlement lived and spoke a unique creole language. ${ }^{15}$ But the Pacific coastal region, where colonial and republican governance had always been weak and patchy, was also reputed to have been home to many runaway slaves and palenques, ${ }^{16}$ so the overall relationship between the Pacific and blackness remained powerful.

In 1991, Colombia underwent a constitutional reform, similar in many ways to the processes of reform that were taking place elsewhere in the region. ${ }^{17}$ In the

\footnotetext{
13 Jaime Arocha, Ombligados de Ananse: Hilos ancestrales y modernos en el Pacífico colombiano (Bogotá: Universidad Nacional de Colombia, 1999); Nina de Friedemann, 'Contextos religiosos en una área negra de Barbacoas, Nariño’, Revista Colombiana de Folclor 4:10 (1966-9), pp. 63-83; Nina de Friedemann, "Troncos" among Black Miners in Colombia', in T. Greaves and W. Culver (eds), Miners and Mining in the Americas (Manchester: Manchester University Press, 1985); Nina de Friedemann and Jaime Arocha, De sol a sol: Génesis, transformación y presencia de los negros en Colombia (Bogotá: Planeta, 1986).

${ }^{14}$ Peter Wade, 'The Cultural Politics of Blackness in Colombia', American Ethnologist 22:2 (1995), pp. 342-58.

${ }^{15}$ Nina de Friedemann, Ma Ngombe: Guerreros y ganaderos en Palenque (Bogotá: Carlos Valencia, 1980); Armin Schwegler, Chi ma nkongo: Lengua y rito ancestrales en El Palenque de San Basilio (Colombia), 2 vols (Frankfurt and Madrid: Vervuert Verlag Iberoamericana, 1996).

${ }^{16}$ William Sharp, 'Manumission, Libres and Black Resistance: The Chocó 1680-1810', in Robert Toplin (ed.), Slavery and Race Relations in Latin America (Westport, CT: Greenwood Press, 1974).

${ }^{17}$ Van Cott, The Friendly Liquidation of the Past; Donna Lee Van Cott, 'Constitutional Reform in the Andes', in Rachel Sieder (ed.), Multiculturalism in Latin America: Indigenous Rights, Diversity and Democracy (Basingstoke: Palgrave Macmillan, 2002); Deborah Yashar, Contesting Citizenship in Latin America: The Rise of Indigenous Movements and the Postliberal Challenge (Cambridge: Cambridge University Press, 2005).
} 
Racism-00-p.qxd 7/2/12 11:28 Page 40

elections to the constituent assembly, indigenous delegates managed to gain a 1 foothold, while no black candidates were elected. An indigenous delegate from the 2 Pacific coastal region undertook to represent the interests of both black and 3 indigenous people in the area. Several measures were included in the new con- 4 stitution which protected and expanded the rights of indigenous peoples. A short 5 transitory article related to rural black communities in the Pacific coastal region 6 was included at the last minute and, two years later, became Law 70 of 1993. This 7 is not the place to assess this legislation; the point I want to emphasise here is that 8 Law 70 privileged the Pacific coastal region as the location of blackness in Colombia. 9 The law addressed the black communities of Colombia (comunidades negras) as 10 'an ethnic group', but at the same time focused explicitly on rural, riverine, black 11 communities occupying state-owned land in the Pacific coastal region and their 12 prospective land rights. Even though it said that rural, riverine, black communities 13 occupying state land in other regions of the country were also covered by the 14 legislation, in practice this caveat had virtually no impact. Thus the law consolidated 15 the idea of the historically and ethnically distinctive black community located in 16 the Pacific coastal region. The legislative category of comunidad negra was an 17 emergent one, created to a significant degree by the very law that claimed to be 18 recognising it, yet it also built on existing, and especially anthropological, con- 19 ceptions of blackness in the Pacific coastal region. Rather like the anthropological 20 conception, it was also a clearly indigenising category: it made black communities 21 look, especially in the eyes of the state, like indigenous communities. The definition 22 of black community in the law makes this very plain: it is 'the set of families of Afro- 23 Colombian descent which possess their own culture, share a history and have their 24 own traditions and customs [. . . ] which reveal and maintain an awareness of identity 25 which distinguish them from other ethnic groups'. ${ }^{18}$

Law 70 had significant effects in the region. By 2005, collective land titles for black communities numbered 132, with an area of 4.7 million hectares, representing about 4 per cent of the national territory. ${ }^{19}$ By comparison, in 2005 indigenous resguardos (land reserves) numbered 710, with an area of about 34 million hectares, representing 30 per cent of the national territory. These figures need to be seen against the results of the 2005 census which showed that Afro-Colombians formed 10.5 per cent and indigenous people 3.4 per cent of the national total (although, of course, most of these Afro-Colombians did not live in rural, riverine communities on state-owned land - on the contrary, most of them lived in cities).

18 'Es el conjunto de familias de ascendencia afrocolombiana que poseen una cultura propia, comparten una historia y tienen sus propias tradiciones y costumbres dentro de la relación campo-poblado, que revelan y conservan conciencia de identidad que las distinguen de otros grupos étnicos' (Ley 70 de 1993, Article 2).

${ }^{19}$ Departamento Administrativo Nacional de Estadística (DANE), Colombia una nación multicultural: Su diversidad étnica (Bogotá: Departamento Administrativo Nacional de Estadística, 2006). 
In the 2000s, while the comunidad negra, the ethnic community, and rural land claims remain central, there has been a discernible shift of attention towards urban black populations, a more racial definition of blackness, and issues of racism. As indicated above, the 2005 census showed most blacks living outside the Pacific coastal region and in cities; this was a key moment in giving some institutional space to blackness. In the 1993 census, a new question had been included asking people if they belonged to a comunidad negra and, if so, which one. The question was a failure as only 1.5 per cent of people ticked this box, which hardly seemed to represent the presence of blackness in the nation. After lengthy negotiations, involving the state, academics and black activist organisations, and sponsored in part by the World Bank and the Inter-American Development Bank, a much more inclusive question appeared on the 2005 census form.

The urban presence of blackness was also being increasingly recognised by academics who began to include city contexts as well as rural ones in their studies of Afro-Colombians. ${ }^{20}$ Meanwhile, black social movements, which for obvious reasons had been working hard in the Pacific coastal region, where land rights were at issue, ${ }^{21}$ also began to look towards cities and urban issues of racism in the labour and housing markets, as well as black culture construed more in terms of cosmopolitan, commodified black style than 'traditions and customs'. ${ }^{22}$ Furthermore, the issue of land titles in the Pacific coastal region had, by chance or by design, coincided with the massive incursion of paramilitary forces into the area, displacing large numbers of black (and indigenous) people into the cities of the interior. ${ }^{23}$ While black social movements protested about displacement and the take-over of land by capitalist interests, they also began to address issues related to the displaced populations in the cities.

${ }^{20}$ Michel Agier et al., Tumaco: Haciendo ciudad (Bogotá: Universidad del Valle, 1999); Olivier Barbary and Fernando Urrea (eds), Gente negra en Colombia, dinámicas sociopolíticas en Cali y el Pacifico (Cali and Paris: CIDSE/Univalle, IRD, Colciencias, 2004); Claudia Mosquera Rosero-Labbé, Acá antes no se veían negros: Estrategias de inserción de migrantes del Pacifico colombiano en Bogotá (Bogotá: Observatorio de Cultura Urbana, 1988); see also Wade, Blackness and Race Mixture.

${ }^{21}$ Libia Grueso, Carlos Rosero and Arturo Escobar, 'The Process of Black Community Organizing in the Southern Pacific Coast of Colombia', in Sonia Alvarez, Evelina Dagnino and Arturo Escobar (eds), Cultures of Politics, Politics of Cultures: Re-Visioning Latin American Social Movements (Boulder, CO: Westview, 1998), pp. 196-219.

${ }^{22}$ Olivier Barbary, Héctor F. Ramírez and Fernando Urrea, 'Identidad y ciudadanía afrocolombiana en el Pacífico y Cali', in Barbary and Urrea (eds), Gente negra en Colombia, pp. 245-82; Peter Wade, 'Working Culture: Making Cultural Identities in Cali, Colombia', Current Anthropology 40:4 (1999), pp. 449-71.

${ }^{23}$ Oscar Almario, 'Dinámica y consecuencias del conflicto armado colombiano en el Pacífico: Limpieza étnica y desterritorialización de afrocolombianos e indígenas y "multiculturalismo" de Estado e indolencia nacional', in Eduardo Restrepo and Axel Rojas (eds), Conflicto e (in)visibilidad: Retos en los estudios de la gente negra en Colombia (Popayán: Universidad del Cauca, 2004); Arturo Escobar, Territories of Difference: Place, Movements, Life, Redes (Durham, NC: Duke University Press, 2008); Mieke Wouters, 'Ethnic Rights under Threat: The Black Peasant Movement against Armed Groups' Pressure in the Chocó, Colombia', Bulletin of Latin American Research 20:4 (2001), pp. 498-519. 
Lastly, the question of racism began to receive more attention, not only from 1 the black social movements, but also from the state. One of the main black 2 organisations, the Proceso de Comunidades Negras (PCN), based in the southern 3 Pacific coastal region, which in 1996 saw racism as a theme with 'little audience', ${ }^{24} 4$ by 2008 had declared as one of its aims the struggle against racism; its website has 5 a link to the Racial Discrimination Observatory, established in 2007 at the private 6 and elite Universidad de los Andes to monitor racism. ${ }^{25}$ In May 2009, the first 7 National Campaign Against Racism was launched with support from the Vice- 8 President.

In sum, although the definition of blackness in terms of localised communities, 10 defined by ancestral occupation and cultural traditions, has by no means disappeared 11 and remains a powerful legislative category, there has undoubtedly been a shift 12 towards a more racialised understanding of blackness. This does not mean that 13 'culture' has been replaced by 'biology', as 'race' is always about the relationship 14 of those two things, or more broadly of nature and culture. ${ }^{26}$ It does mean that the 15 notion of blackness has expanded beyond a narrow notion of ethnic particularity, 16 derived from the particular history of Colombia's Pacific coastal region, and begun 17 to encompass blackness as a category that is rooted in a colonial history of the enslavement of Africans.

$\begin{array}{ll} & 19 \\ & 20 \\ \text { Brazil } & 21 \\ & 22\end{array}$

Brazil 22

While similar in many respects to Colombia, in terms of its ethnic and racial 24 structures and relations, Brazil diverges from Colombia, first insofar as blackness 25 and the idea of Africa formed a more salient element in public representations of 26 national identity, prior to any shifts towards official multiculturalism that took place 27 in the late twentieth century. Slavery was abolished in Brazil in 1888 and slaves 28 had been imported in large numbers into Brazil from Africa until at least 1860. ${ }^{27} \quad 29$ In contrast, slavery was already a weak institution in Colombia when it was 30

${ }^{24}$ Alvaro Pedrosa et al., 'Movimiento negro, identidad y territorio: Entrevista con la Organización de Comunidades Negras', in Arturo Escobar and Alvaro Pedrosa (eds), Pacífico: ¿desarrollo o biodiversidad? Estado, capital y movimientos sociales en el Pacífico colombiano (Bogotá: CEREC, 1996), pp. 245-65, see p. 251.

${ }^{25}$ See the PCN website, www.renacientes.org/ (accessed 6 May 2010). See also the Observatory site, http://odr.uniandes.edu.co/ (accessed 6 May 2010); and César Rodríguez Garavito, Tatiana Alfonso Sierra and Isabel Cavelier Adarve, Informe sobre discriminación racial y derechos de la población afrocolombiana: Raza y derechos humanos en Colombia (Bogotá: Universidad de los Andes, 2009). ${ }^{26}$ David Theo Goldberg, Racist Culture: Philosophy and the Politics of Meaning (Oxford: Blackwell, 1993); Peter Wade, Race, Nature and Culture: An Anthropological Perspective (London: Pluto Press, 2002).

${ }^{27}$ Philip Curtin, The Atlantic Slave Trade: A Census (Madison: University of Wisconsin Press, 1969), p. 234.

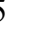

6

7

8
. 
Racism-00-p.qxd 7/2/12 11:28 Page 43

abolished in 1851, and relatively few slaves had been imported from Africa in the preceding decades. After abolition, black people, by any measure, formed a much larger proportion of the population in Brazil than in Colombia, and they were distributed differently too. Although certain areas (such as Salvador) were strongly associated with blackness, and with relative poverty and 'backwardness', an area such as Rio de Janeiro, which was unequivocally central to the nation, also had a substantial black population.

This demographic reality underlay the representation of Brazil by intellectuals in the 1930s as a highly mixed country, with important black/African components. Writers such as Arthur Ramos and Edison Carneiro focused scholarly attention on Afro-Brazilians in ways unparalleled in Colombia at the time, while Gilberto Freyre famously recast Brazil's mixture as a positive trait, against the grain of the eugenic thought popular in Latin America, Europe and North America in the period. Granted this view of Brazil was very assimilationist and in fact perpetuated some of the whitening ideologies of previous decades, but it was still a much more forceful embracing of mixture, including its component of African ancestry, than one could find in Colombia during these decades. ${ }^{28}$

An interesting comparison is that between Brazilian samba and Colombian cumbia. The two genres had rather similar trajectories, in starting out as nominally 'black' musical styles and becoming national icons, having been significantly whitened along the way; but samba began this journey much earlier than cumbia and yet arguably retained more of a black image than cumbia did, at least when considering their urban, commercial, popular musical forms. ${ }^{29}$ Clearer yet is the difference between the two countries in terms of social movements seeking to redress racial inequalities and promote equal rights for black people: Brazil's black press, centred on São Paulo in the 1910s and 1920s, and the short-lived Frente Negra Brasileira founded in 1931, have no equivalent in Colombia. ${ }^{30}$

In terms of scholarly attention to race, there is a tradition of studying race relations in Brazil that goes back to the 1950s and the well-known UNESCO studies which sought to understand Brazil's reputed 'racial democracy' in the wake of Nazi racism. These early studies were mainly urban, ${ }^{31}$ and focused on discrimination against a racialised category of citizens who were culturally very similar to everyone else. While some studies focused on the culturally distinctive patterns of Afro-

\footnotetext{
${ }^{28}$ Jan Hoffman French, Legalizing Identities: Becoming Black or Indian in Brazil's Northeast (Chapel Hill: University of North Carolina Press, 2009), p. 156; Jeffrey D. Needell, 'Identity, Race, Gender, and Modernity in the Origins of Gilberto Freyre's Oeuvre', American Historical Review 100:1 (1995), pp. 51-77; Thomas Skidmore, Black into White: Race and Nationality in Brazilian Thought (New York: Oxford University Press, 1974); see also the essay by Guimarães, in this volume (Chapter 1).

${ }^{29}$ Hermano Vianna, The Mystery of Samba: Popular Music and National Identity in Brazil (Chapel Hill: University of North Carolina Press, 1999); Wade, Music, Race and Nation.

${ }^{30}$ See also Guimarães, this volume.

${ }^{31}$ Although see Charles Wagley (ed.), Race and Class in Rural Brazil (Paris: UNESCO, 1952).
} 
Brazilian religion, ${ }^{32}$ the main focus was on race, capitalism and social change. These themes have proved durable and, although scholarly work on race in Brazil has diversified, there is still a strong leaning towards race relations, racism and racial politics, usually in an urban context, which contrasts markedly with the situation in Colombia, where the culture of black communities, especially those of the Pacific coastal region, seen as distinctive, was the key focus until much more recently. ${ }^{33}$

It is in this context that we have to understand Brazil's 1988 constitutional reform, which opened the door to land claims by so-called remanescentes das comunidades dos quilombos (remnants, remainders or survivors of quilombo communities), in a legislative move that looks rather similar to Colombia's Law 70. Of course, one difference is the explicit mention of maroon communities in the Brazilian case, but in fact the two trajectories run along parallel or converging lines.

Initially, the Brazilian constitutional clause had very little impact. There was little debate about it in the constituent assembly, compared to the lobbying carried out by indigenous delegates and organisations. Contrast Colombia where, although issues around indigenous peoples similarly took precedence over those about AfroColombians, there had also been a good deal of debate about whether black communities should be recognised in any way, and black organisations had mobilised and occupied buildings such as the Haitian Embassy in Bogotá. French argues that the quilombo clause made it into the constitution partly because the black social movement had long adopted the famous quilombo of Palmares as a key symbol, but also because the state saw old quilombos as a kind of national patrimony, which symbolised the struggle of all Brazilians against colonial domination. ${ }^{34}$ The target of the clause was rather ill-defined: compared to the Colombian case, where Law 70 was clearly aimed at rural, riverine communities in the Pacific coastal region, it was not very clear how much ground was potentially being ceded in Brazil (although the assumption seems to have been that it was not much).

After 1988, not a great deal happened until the mid-1990s, when definitions of quilombo began to change. ${ }^{35}$ Until 1994, there had been quite a strict adherence to the need to prove that the community making a land claim actually descended from a historical quilombo; this was despite arguments from the black social movements that a more inclusive definition was needed. In 1994, the Palmares

${ }^{32}$ E.g. Roger Bastide, The African Religions of Brazil: Towards a Sociology of the Interpenetration of Civilizations (Baltimore: Johns Hopkins University Press, 1978).

${ }^{33}$ Antonio Sérgio Guimarães, Racismo e anti-racismo no Brasil (São Paulo: Editora 34, 1999); Michael Hanchard (ed.), Racial Politics in Contemporary Brazil (Durham, NC: Duke University Press, 1999); Rebecca Reichmann (ed.), Race in Contemporary Brazil: From Indifference to Inequality (University Park, PA: Pennsylvania State University Press, 1999); Robin E. Sheriff, Dreaming Equality: Color, Race, and Racism in Urban Brazil (New Brunswick, NJ: Rutgers University Press, 2001).

${ }^{34}$ French, Legalizing Identities, p. 94.

${ }^{35}$ French, Legalizing Identities, pp. 95-8.

\section{1} 2 3 4 5 6 7 8 9 
Foundation, created in 1988 to, among other things, administer the quilombo land claims process, began to shift its ground towards a broader definition that included rural black communities (a category already established in academic studies since the 1980s), populated by people who were presumed to descend from slaves, who lived at a subsistence level and whose cultural practices were linked to the ancestral past in a way that was interpreted as constituting a history of resistance, even if there was no particular history of insurrection or rebellion. There was no need to establish a specific link to fugitive slaves, to African-derived culture. Increasingly, remanescentes de quilombos were recognised as emergent phenomena: people could re-discover their quilombola identity, ${ }^{36}$ often prompted by outsiders such as priests and legitimated by experts such as anthropologists.

As a result of this change in criteria for recognition, there has been a great increase in the number of communities claiming quilombo status: by November 2003, 743 had been recognised, representing some 30.6 million hectares of land or 3.6 per cent of the national territory, of which however only seventy-one had received land titles. Another sixty titles were issued between 2003 and 2008, giving a total titled land area of about 1.25 million hectares. ${ }^{37}$ As of January 2009, 1,305 had been recognised by the Palmares Foundation and some estimates put the figure at 2,000-3,000 communities. ${ }^{38}$ As in Colombia, where at least one 'black community' was recognised in the city of Santa Marta (although land title was not given), some claims have also emerged for urban quilombos in Brazil. ${ }^{39}$

The role of colour here was ambiguous. On the one hand, the people claiming quilombola status were often mixed-race peasants, who by no means identified straightforwardly as negros and might even reject such a label. On the other hand, the presumption of a generalised descent from slaves suggested that colour (darkness of skin, some phenotypical traits associated with negros) could be a marker of membership of a potential quilombola community.

French interprets this mid-1990s shift as a move from race to ethnicity, from ideas of descent to ideas of culture and territory. I am not sure the shift is quite so clear. Although the need to prove descent from a historical quilombo clearly

\footnotetext{
36 José Mauricio Andion Arruti, 'A emergência dos "remanescentes": Notas para o diálogo entre indígenas e quilombolas', Mana. Estudos de Antropología Social 3:2 (1997), pp. 7-38; José Mauricio Andion Arruti, 'Comunidades negras rurais: Entre a memória e o desejo', Tempo e Presença 298 (1998) pp. $15-18$.

${ }^{37}$ See www.nead.org.br/index.php?acao=princ\&id=6\&id_prin=46 (accessed 7 May 2010); Noticias Agrárias, 24-30 November 2003, no. 212, www.nead.org.br/boletim/boletim.php?boletim=212\& noticia=891 (accessed 12 May 2010); and www.palmares.gov.br/003/00301015.jsp?ttCD_CHAVE= 2702 (accessed 7 May 2010).

${ }^{38}$ See www.palmares.gov.br/003/00301009.jsp?ttCD_CHAVE=1853 (accessed 7 May 2010).

${ }^{39}$ For Colombia, see Peter Wade, 'The Colombian Pacific in Perspective', Journal of Latin American Anthropology 7:2 (2002), pp. 2-33, see p. 18; for Brazil, see Lourdes de Fátima Bezerra Carril, 'Quilombo, território e geografia', Agrária 3 (2006), pp. 156-71, www.geografia.fflch.usp.br/revista agraria/revistas/3/8_carril.pdf (accessed 7 May 2010).
} 
broadens the definition, the idea of slave descent and the ambiguous role of colour and racialised appearance seem to indicate that race did not disappear as a criterion, especially if one bears in mind that race is always about culture as well as nature.

This aside, I would argue that the shift parallels the longer-term Colombian shift towards seeing blackness as a cultural phenomenon located in the Pacific coastal region. There too, issues of descent and appearance did not disappear, as the black people of the Pacific mainly fitted into Colombian stereotypes of what a negro looked like, but the point is that all other such negros in the country were effectively left out of this categorisation. In both Brazil and Colombia, black communities were effectively assimilated to dominant images of what an indigenous community looked like, while at the same time criteria of ethnicity (culture) and race (descent, appearance) intertwined and blurred. This, I think, responds to the ambiguous status of blackness in these Latin American contexts: are black people culturally different and 'other', like indigenous people; or are they simply citizens, culturally the same as everyone else, but marked by an inherited phenotype that acts as a stigma?

Meanwhile, the previous image of blackness in Brazil as a racial category referring mainly to urban black people, identified principally by inherited phenotype, located disadvantageously in residential and labour markets, subject to racism and struggling for equality - was by no means displaced by the quilombo clause in the way that Colombia's Law 70 had consolidated the definition of blackness as a marginal, regional culture and, for a time, more or less displaced a more racialised and inclusive definition of blackness. On the contrary, it could be argued that, however fast the quilombo land movement is growing, the real ground for black identity and politics in Brazil is still firmly in urban areas and not related to land titles. It is this that has underlain the emergence of controversial affirmative action policies in Brazil in ways that are still incipient - and as yet remarkably uncontroversial - in Colombia. The heated debates over the imposition of programmes of racial quotas for entry into federal universities, the creation of SEPPIR (Secretariat for Policies for the Promotion of Racial Equality) and the proposed Statute of Racial Equality, which would spread the coverage of affirmative action and racial quotas much further - all these are testament to the racial nature of blackness in Brazil. These measures are seen to strike at the heart of ideas of Brazilian national identity and to differentiate the notion of 'citizen' in ways that the affirmative action of Colombia's Law 70, directed at a regional ethnic group, did not.

The urban, racial character of blackness in Brazil, compared to Colombia, is also evident in the gradual emergence of a black middle class, which overtly identifies with notions of beleza negra (black beauty) and consumption of fashion and style based on a black aesthetic, especially of the body. ${ }^{40}$ While this may still

${ }^{40}$ Peter Fry, 'Estética e política: Relações entre “raça”, publicidade e produção da beleza no Brasil', in Mirian Goldenberg (ed.), Nu e vestido: dez antropólogos revelam a cultura do corpo carioca (Rio de Janeiro: Record, 2002); Livio Sansone, Blackness Without Ethnicity: Constructing Race in Brazil (Basingstoke: Palgrave Macmillan, 2003). 1 2 3 4 5 6 7 8 9 
not be a very powerful trend in Brazil, it is certainly more noticeable there than in Colombia, partly because the Colombian black middle class is smaller, but also because the urban presence of blackness, particularly of middle-class blackness, is more muted.

\section{Comparative lessons}

Juliet Hooker's characterisation of Colombia and Brazil as recognising blacks as both 'racial groups' and 'cultural groups' may appear confusing, but it actually directs us to a central feature of both countries and, arguably, of Latin America more widely. In both places, legislation and multiculturalist policies have shifted between, on the one hand, ideas that emphasise racialised, inherited appearance, perhaps with some acknowledgement of an African origin, and which refer to black people as a national category (and indeed a transnational one); and, on the other hand, ideas that emphasise local, cultural histories and bounded community territories, often assimilating these to images of the indigenous community, and which construct black people as a category that does not traverse the nation. These emphases are not mutually exclusive, but overlap and shade into each other: pointing to inherited appearance can also entrain ideas about local histories, and vice versa. As Guimarães argues (in this volume), a racial classificatory binary can coexist with multiple other categories of identity. Still, one can see the political effects of relying on one emphasis more than the other. In Colombia, the effect of Law 70 in limiting the whole issue of blackness to the Pacific coastal region has been evident.

However, a more ethnic-cultural emphasis - and the modelling of black rights after indigenous rights which it often entrains - while constrictive at first sight is not as simple as it seems. French argues that, in Brazil, the flexibility with which the same people can opt to make claims as indigenous or as black works to open up options. ${ }^{41}$ Both options rely on an ethnic-cultural emphasis, but they multiply the overall possibilities for engagement and mobilisation. Taking a different tack - which also nuances the difference between Hooker's first and second categories - Anderson thinks that, for Honduras, a discourse of ethnic rootedness can coexist quite easily with a discourse of urban cosmopolitan blackness. ${ }^{42}$ Again, more options are better than fewer.

The Colombian and Brazilian cases indicate that a focus on cultural difference and ethnic distinctiveness may be useful in the struggle for local land rights, but it is also necessary to complement this with a focus on racism (as it affects housing, employment and aesthetics). If Law 70 had closed down the debate and restricted

\footnotetext{
${ }^{41}$ French, Legalizing Identities.

42 Anderson, Black and Indigenous.
} 
it only to land rights in the Pacific coastal region, this would have been a negative 1 effect. In fact, it arguably opened up new horizons for talking about blackness in 2 other, more inclusive ways, which begin to converge with a Brazilian-style 3 discourse about blackness.

Whether Colombia should follow Brazil towards racial quotas as a mechanism 5 to address racism is a more difficult question. Quotas seem to have a positive effect 6 in publicising and naming the problem of racial inequality, but it is also the case 7 that many black Brazilian students want to avoid using racial quotas, because they 8 suggest the student unfairly obtained a university place and is not up to scratch 9 academically. The same students are much less allergic to public school quotas, 10 which preferentially admit students from public schools, and which should carry 11 the same stigma as the racial quotas. This seems to suggest that (a) the fact of 12 being black and thus subject to racism is not seen as worthy of reparation, compared 13 to the fact of having been poor and only able to attend public school, and (b) it is 14 the possibility of being identified by skin colour as the beneficiary of a racial quota 15 that makes the students uncomfortable. Both suggestions indicate that quotas are 16 actually needed in order to force into the open discussions about the moral 17 worthiness of racially-oriented reparation.

In Colombia, thus far, affirmative actions have not caused controversy. They have consisted of small-scale and assistentialist measures (special grants and places are available to black students, but there are no quotas to fill, which looks less 'unfair' towards non-blacks) and/or they have comprised indirect actions, which target whole regions, rather than individuals. My hunch is that Colombia's convergence with Brazil will stop short of the kind of quota systems that have been put in place there. There is no indication that Colombia's political elites will take this kind of (apparently) radical action; instead it seems likely that they will prefer less controversial and more tokenistic measures.

\section{4}

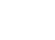
8

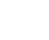
0 1 2 